\title{
ANTIGENIC MODIFICATIONS ASSOCIATED WITH "SPONTANEOUS" MALIGNANT ALTERATIONS OF MOUSE FIBROBLASTS PROPAGATED IN VITRO
}

\author{
by \\ JØRGEN v.F. KIELER, YOSHIFUMI ODA, KAY ULRICH \\ AND BER THE M. WILLUMSEN \\ The Fibiger Institute, Copenhagen, Denmark \\ under the Danish Cancer Society
}

\begin{abstract}
Keywords: "Spontaneous" transformation in vitro, rejection antigens, humoral immune response, cell-mediated immune response
\end{abstract}

\begin{abstract}
Two types of "spontaneous" malignant alteration in vitro of ST/a mouse lung fibroblasts (ST-L) have been observed. In contrast to cells which retained their fibroblastic appearance (RST-L cells), cells showing morphological signs of transformation ( $\mathrm{R}^{+} \mathrm{ST}-\mathrm{L}$ cells) developed strong isoimmunizing properties.

Both types of cells expressed MuLV antigens which were found to be responsible for serum as well as cell-mediated immune reactions in vitro. The higher concentration of $\mathrm{gp} 70 \mathrm{in} \mathrm{R}^{+} \mathrm{cells}$ as compared to $\mathrm{R}$ cells and possibly also the morphological differences in surface structure between the two cell types may account for the differences in immunogenicity.

Preimmunization with $\mathrm{R}^{+} \mathrm{ST}-\mathrm{L}$ cells protected ST/a mice against secondary challenge with two ascites tumors (STABAL leukemia and Ehrlich). RST-L cells did not have a similar protective effect. However, the two ascites tumors only showed weak or no cross-reactions in vitro with sera and lymphoid cells from ST/a mice sensitized to $\mathrm{R}^{+} \mathrm{ST}$ - $\mathrm{L}$ cells, and the in vitro reaction between the latter cells and sera or lymphoid cells from mice immunized against the two ascites tumors was moderate. This discrepancy between in vivo and in vitro observations is discussed.
\end{abstract}

\section{INTRODUCTION}

The apparently spontaneous malignant alteration in vitro of ST/a mouse lung fibroblasts (ST-L) has been studied for a number of years in this laboratory. In some cell lines the development of tumorigenic properties as demonstrated by retransplantation into newborn syngeneic recipients was accompanied by various changes of cellular morphology and other signs of transformation which have been de- scribed in detail elsewhere (9), while in other cell lines no such changes were observed. Thus, two types of tumorigenic cell lines emerged; one characterized by the round shape of the cells and altered growth pattern, and another one characterized by the fibroblastic appearance of the cells and normal growth pattern (see Table I). In the following these two types of cells will be referred to as round cells or $\mathrm{R}^{+} \mathrm{ST}-\mathrm{L}$ and fibroblastic or R'ST-L cells, respectively. 
Table I.

Signs of "spontaneous" transformation of ST/a mouse lung cells (ST-L) propagated in vitro (1).

\begin{tabular}{|c|c|c|}
\hline $\begin{array}{l}\text { Morphol. } \\
\text { transformation" }\end{array}$ & $\mathbf{R}^{+}$ & $\mathrm{R}^{-}$ \\
\hline Cell lines & $\begin{array}{l}\text { ST-L1 } \\
\text { ST-L4 }\end{array}$ & $\begin{array}{l}\text { ST-L7, ST-L8, } \\
\text { ST-L9, ST-L22, } \\
\text { ST-L67, 24.pass. }\end{array}$ \\
\hline $\begin{array}{l}\text { Cytology } \\
\text { Cell surface }\end{array}$ & $\begin{array}{l}\text { Round } \\
+++ \text { microvilli }\end{array}$ & $\begin{array}{l}\text { Flat, fibroblastic } \\
\text { (+) microvilli }\end{array}$ \\
\hline $\begin{array}{l}\text { Chromosomes } \\
\text { Median no. }\end{array}$ & $\begin{array}{l}\text { Aneuploid } \\
69-79\end{array}$ & $\begin{array}{l}\text { Aneuploid } \\
52-68\end{array}$ \\
\hline $\begin{array}{l}\text { Growth pattern: } \\
\text { Multilayer growth } \\
\text { Growth without serum } \\
\text { Saturation density } \\
\text { Invasive growth in vitro (9) } \\
\text { Colonies in semisoft agar }\end{array}$ & $\begin{array}{l}+ \\
+ \\
\text { increased } \\
+ \\
+\end{array}$ & $\begin{array}{l}- \\
- \\
\text { normal } \\
+ \\
-\end{array}$ \\
\hline $\begin{array}{l}\text { Expression of viral antigens } \\
\text { p30 } \\
\text { gp } 70\end{array}$ & $\begin{array}{l}++ \\
+++\end{array}$ & $\begin{array}{l}+++ \\
+\end{array}$ \\
\hline $\begin{array}{l}\text { Tumorgenicity: } \\
\text { In newborn } \mathrm{ST} / \mathrm{a} \text { mice } \\
\text { In adult } \mathrm{ST} / \mathrm{a} \text { mice }\end{array}$ & + & $\begin{array}{l}+ \\
+\end{array}$ \\
\hline
\end{tabular}

1) Morphological transformation was described as round cell transformation $\left(\mathrm{R}^{+}\right)$,

while morphologically unaltered cells were given the designation $\mathbf{R}^{-}$.

The $\mathbf{R}^{+}$cells produced invasively growing, occasionally metastasizing sarcomas in newborn animals and in immunosuppressed adult animals, but not in immunocompetent hosts. In contrast, cells which had undergone malignant alteration without any signs of $\mathrm{R}^{+}$transformation readily produced sarcomas in immunocompetent hosts.

The development of new transplantation antigens associated with "spontaneous" malignant alteration has been studied by a number of investigators in active protection experiments (for review, see 7). In these experiments antigenic cells were able to grow in non-immunized mice, but not in immunized recipients.

In contrast to previous studies the $\mathrm{R}^{+} \mathrm{ST}-\mathrm{L}$ cells are rejected even by non-immunized immunocompetent recipients. This precludes protection experiments employing the $\mathbf{R}^{+}$cells for secondary challenge, since both immunized and non-immunized animals would reject the challenge. However, the immunogenic properties of $\mathrm{R}^{+} \mathrm{ST}$ - $\mathrm{L}$ cells could be demonstrated by their ability to protect the recipients against two ascites tumors carried in ST/a mice (9).

The present work was carried out in order to study whether the in vivo expression of rejection antigens can be correlated with the in vitro demonstration of serum and cellmediated immune responses to $\mathrm{ST}-\mathrm{L}$ cells injected into mice of the inbred strain of origin.

\section{MATERIALS AND METHODS}

\section{In vitro propagated cell lines}

The main characteristics of the $\mathrm{R}^{+}$and $\mathrm{R}^{-} \mathrm{ST}-\mathrm{L}$ cells are summarized in Table $\mathrm{I}$. Both cell types were propagated in synthetic Fib. 41B medium (8) supplemented with $20 \%$ fetal bovine serum (FBS). The medium was changed three times 
weekly and the cells were transferred without the use of trypsin.

The cloned SC-1 cell line is derived from a feral mouse embryo. It does not express C-type virus (5). This cell line was propagated in MEM (2) with 5\% FBS.

\section{Tumors}

ST-L tumors of R ST-L origin were produced by sc injection of the cultured cells into normal adult recipients.

The STABAL-2 leukemia was induced in an ST/a female mouse by skin painting with dimethylbenzanthracene (12). This tumor is propagated as an ascites tumor in inbred ST/a mice. $\mathrm{TD}_{s 0}$ was less than 100 cells. Mean survival after ip inoculation of $10^{6}$ cells was $16.5 \pm 2.5$ days.

The hypotetraploid Ehrlich ascites tumor has been carried in the ST/a mouse strain in this laboratory for 24 years. $\mathrm{TD}_{50}$ and mean survival were similar to that of STABAL-2 ( $<100$ cells and $17 \pm 1.6$ days, respectively).

\section{Immunization}

Young, adult ST/a mice were immunized against $R^{+} S T-L$ cells by weekly sc injections of $5 \times 10^{6}$ cells. In active protection experiments and for the demonstration of cellmediated immunity in vitro 2 injections were given; for serum production the donors received 4-6 weekly injections before bleeding from the retroorbital sinus.

Immunization against tumorigenic $\mathrm{R}^{-} \mathrm{ST}-\mathrm{L}$ cells, Ehrlich ascites tumor and STABAL-2 leukemia was carried out by the sc injection of $5 \times 10^{6} \mathrm{X}$-irradiated cells $(2.000 \mathrm{rad})$.

\section{Indirect membrane immunofluorescence test}

The indirect membrane immunofluorescence test (13) was carried out using FITC conjugated goat anti-mouse gamma globulin (Hyland) diluted $1: 4$ or $1: 8$ with PBS for staining. Based on countings of 100 cells the fluorescence index (FI) was calculated from the formula $\frac{a-b}{a}$, where $a$ represents the percentage of fluorescence negative cells treated with control serum and $b$ the percentage of fluorescence negative cells treated with antiserum (11).

Double absorption of specific antisera was carried out at dilutions 1:16 - 1:64 with equal volumes of packed cells or minced tissue. After absorption for one hour at $37^{\circ} \mathrm{C}$ the absorbing material was renewed and the samples were left overnight at $4{ }^{\circ} \mathrm{C}$.

\section{Lymphocyte cytotoxicity in vitro}

Lymphocyte toxicity was studied by the micro tissue culture method originally described by ULRICH and KIELER (19). Lymph node cells from non-immunized and immunized mice were added to monolayer cultures of $\mathrm{R}^{+} \mathrm{ST}-\mathrm{LI}$ cells previously established in Linbro Disposo Trays, FB-48 clear with 12 flatbottomed $0.5 \mathrm{ml}$ cups. The number of target cells remaining in the cultures was counted after 24 and 40 hours of incubation.

\section{Migration inhibition test}

The migration inhibition of mixed thymus and lymph node cells was studied by a modification of the capillary method as previously described (16). Intact tumor cells were used as antigen at a concentration of $10^{4}$ cells per $\mathrm{ml}$. Each group consisted of 6 capillary tubes. After 22-24 hours of incubation in a $\mathrm{CO}_{2}$ incubator the migration areas were measured, and the migration inhibition index (M.I.I.) of the individual test cultures was calculated as follows:

\section{M.I.I. = migration area with antigen}

mean migration area of ctr. without antigen

\section{The indirect lymphokine test}

Details of this test have been described previously (10). ST/a mice were immunized against the cells to be investigated as described. Mixed cultures of sensitized spleen cells and tumor cells (stimulator cells) were incubated at $37^{\circ} \mathrm{C}$ and $5 \%$ $\mathrm{CO}_{2}$ overnight together with control cultures containing 1) medium alone, 2) stimulator cells alone, 3) non-sensitized spleen cells alone, 4) non-sensitized spleen cells and stimulator cells, and 5) sensitized spleen cells alone.

After incubation the supernatant media were 
harvested and their inhibitory effect on the uptake of $3 \mathrm{H}-\mathrm{TdR}$ in microtest cultures was studied. $\mathbf{R}^{+}$ST-L 1 cells served as test cells in all cases. A significant difference between the inhibitory effect of the supernatants from mixed cultures of sensitized spleen cells and stimulator cells and the supernatants from all five controls mentioned above was the criterion required for a positive test. The relative inhibition was calculated as follows: $\left(1-\frac{a}{b}\right) \times 100$ where a represents the incorporation of $3 \mathrm{H}-\mathrm{TdR}(\mathrm{cpm})$ in test cultures treated with supernatants from mixed cultures of sensitized spleen cells and stimulator cells, and $b$ the corresponding figures obtained with supernatants from mixed cultures with nonsensitized spleen cells.

\section{Demonstration of infectious murine leukemia virus (MuLV)}

MuLV was demonstrated by a modification of the XC plaque test (17). All cultures were grown in Eagle's minimal essential medium (MEM) supplemented with 10\% FBS. Cells from the various cell lines to be tested were seeded into five centimeter Petri dishes (Falcon). Medium was discarded after 2 days and the monolayer of cells in each Petri dish exposed to UV irradiation followed by addition of $7.5 \times 10^{4} \mathrm{SC}-1$ cells in medium containing $5 \mu \mathrm{g} / \mathrm{ml}$ polybrene. Ascites cells to be tested were washed in PBS and inoculated into Petri dishes, which had been seeded the previous day with $7.5 \times 10^{4} \mathrm{SC}$ - 1 cells in MEM + FBS containing $5 \mu \mathrm{g} / \mathrm{ml}$ polybrene. The medium was changed after 24 hours of cocultivation and 3-4 days later two cultures of each set of three were processed for the XC-test, whereas the third culture was reseeded for further testing as indicated.

\section{Demonstration of MuLV by the peroxidase antibody plaque assay (PAPA)}

This assay was performed as described by NExø (14) using rabbit antiserum to the MuLV protein $\mathrm{p} 30$, and peroxidase conjugated goatimmunoglobulins to rabbit IgG, (Nordic Pharmaceuticals, Tillbury, Holland). Before treatment with the anti-p30 serum the cells were washed in ice-cold PBS, immediately fixed for 2 min in methanol, and air-dried. Thus, the assay was developed to demonstrate the presence of intracellular p30.

\section{RESULTS}

\section{ACTIVE PROTECTION EXPERIMENTS}

A. Lack of protection against tumors of $R^{-} S T-L$ origin after immunization with cultured $R^{+}$or R'ST-L cells.

Adult ST/a mice were immunized with one of two malignant cell lines (ST-L1 and ST-L4) which had undergone $\mathrm{R}^{+}$transformation, or $\mathrm{X}$-irradiated cells of four malignant cell lines (ST-L7, ST-L8, ST-L9 and ST-L22) which had not $\left(\mathbf{R}^{-}\right)$. Subsequently, these mice were chal-

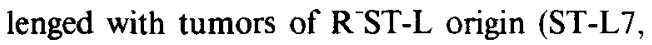
ST-L8, ST-L9 or ST-L22) produced in non-conditioned adult mice, or cultured R-ST-L cells. No protective effect was observed (data not presented).

\section{B. Cross-reactions with STABAL and Ehrlich ascites tumors.}

From data presented in Table II it is seen that immunization of ST/a mice with the non-tumorigenic ST-L108 and ST-L109 cell lines and the tumorigenic R'ST-L22 cell line had no significant protective effect against secondary ip challenge with $10^{3}$ STABAL and Ehrlich ascites tumors, while preimmunization with $\mathrm{R}^{+} \mathrm{ST}$-L1, STABAL and Ehrlich offered good protection against the two ascites tumors injected ip at a dose of $10^{5}$ per mouse. It is also seen that the protective effect did not correlate with the presence of MuLV as demonstrated by the peroxidase antibody plaque assay for $\mathrm{p} 30$.

\section{INDIRECT MEMBRANE}

\section{IMMUNOFLUORESCENCE STUDIES}

In order to investigate whether the protective cross-reactions between $\mathbf{R}^{+}$ST-L cells and STABAL and Ehrlich ascites tumors correlates with the presence of antigens detectable by the immunofluorescence test, isoantisera were raised in adult ST/a mice. The reactions and cross-reactions of these isoantisera with 8 diffe- 
Table II.

Active protection against secondary challenge with STABAL-2 and Ehrlich ascites tumors.

\begin{tabular}{|c|c|c|c|c|c|c|c|c|}
\hline \multicolumn{4}{|c|}{ IMMUNIZATION } & \multicolumn{5}{|c|}{ CHALLENGE } \\
\hline \multirow{2}{*}{ Cells" } & \multirow{2}{*}{$\begin{array}{l}\text { Round } \\
\text { cell } \\
\text { transf.+/- }\end{array}$} & \multirow{2}{*}{$\begin{array}{l}\text { Tumori- } \\
\text { genic. } \\
+/-\end{array}$} & \multirow{2}{*}{$\begin{array}{l}\text { PAPA }^{21} \\
+/-\end{array}$} & \multirow{2}{*}{$\begin{array}{l}\text { No. of } \\
\text { cells }\end{array}$} & \multicolumn{4}{|c|}{ Number of takes/total } \\
\hline & & & & & $\begin{array}{l}\text { STABAL-2 } \\
\text { Imm. }\end{array}$ & Ctr. & $\begin{array}{l}\text { EHRLICH } \\
\text { Imm. }\end{array}$ & Ctr. \\
\hline ST-L108 & - & - & - & $\begin{array}{l}10^{3} \\
10^{4}\end{array}$ & $\begin{array}{l}9 / 10 \\
9 / 9\end{array}$ & $\begin{array}{l}8 / 10 \\
9 / 10\end{array}$ & $\begin{array}{l}13 / 20 \\
13 / 14\end{array}$ & $\begin{array}{r}9 / 20 \\
12 / 15\end{array}$ \\
\hline ST-L109 & - & - & + & $\begin{array}{l}10^{3} \\
10^{4}\end{array}$ & $\begin{array}{c}10 / 10 \\
9 / 9\end{array}$ & $\begin{array}{l}8 / 10 \\
9 / 10\end{array}$ & $\begin{array}{l}16 / 20 \\
14 / 15\end{array}$ & $\begin{array}{l}11 / 20 \\
11 / 15\end{array}$ \\
\hline ST-L22 & $\cdot$ & + & - & $\begin{array}{l}10^{3} \\
10^{4} \\
10^{5}\end{array}$ & $\begin{array}{r}6 / 10 \\
8 / 10 \\
10 / 10\end{array}$ & $\begin{array}{r}8 / 10 \\
10 / 10 \\
10 / 10\end{array}$ & $\begin{array}{r}6 / 10 \\
7 / 10 \\
10 / 10\end{array}$ & $\begin{array}{r}7 / 10 \\
9 / 10 \\
10 / 10\end{array}$ \\
\hline ST-L1 & + & + & + & $\begin{array}{l}10^{4} \\
10^{5}\end{array}$ & $\begin{array}{l}0 / 10 \\
3 / 10\end{array}$ & $\begin{array}{l}10 / 10 \\
10 / 10\end{array}$ & $\begin{array}{l}0 / 10 \\
0 / 10\end{array}$ & $\begin{array}{r}10 / 10 \\
9 / 10\end{array}$ \\
\hline STABAL-2 & & + & + & $\begin{array}{l}10^{4} \\
10^{5}\end{array}$ & $\begin{array}{l}0 / 10 \\
1 / 10\end{array}$ & $\begin{array}{r}9 / 10 \\
10 / 10\end{array}$ & $\begin{array}{l}0 / 10 \\
0 / 10\end{array}$ & $\begin{array}{r}9 / 10 \\
10 / 10\end{array}$ \\
\hline EHRLICH & & + & + & $\begin{array}{l}10^{4} \\
10^{5}\end{array}$ & $\begin{array}{l}0 / 10 \\
0 / 10\end{array}$ & $\begin{array}{l}10 / 10 \\
10 / 10\end{array}$ & $\begin{array}{l}0 / 10 \\
0 / 10\end{array}$ & $\begin{array}{l}10 / 10 \\
10 / 10\end{array}$ \\
\hline
\end{tabular}

1) $5 \times 10^{6}$ irradiated $(2000 \mathrm{r})$ cells were injected $\mathrm{sc}$ twice at 1 weeks interval.

2) $\mathrm{PAPA}=$ Perosidaseantibody plaque assay for $\mathrm{p} 30$ (14).

rent cell lines and 2 ascites tumors were studied by the indirect membrane immunofluorescence test at $5-7$ serial dilutions.

Some of the results are shown in Table III, from which it is seen that strong antisera were raised against two malignant $\mathbf{R}^{+} \mathrm{ST}-\mathrm{L}$ cell lines (ST-L1 and ST-L4). Pronounced cross-reactions were seen between ST-L1 and ST-L4 cells and their respective antisera.
The reactions of malignant cells which had not undergone $\mathrm{R}^{+}$cell transformation (ST-L9 and ST-L22) were in most cases doubtful or completely negative. However, maximal immunofluorescence indices between 0.3 and 0.5 indicate that weak reactions did occur.

No reactions were seen between anti-ST-L1 serum and the non-malignant ST-L66 and STL67 cells in their 6th and 7th in vitro passage,

Table III.

Indirect immunofluorescence studies. Cross-reactions between tumorigenic, PAPA ${ }^{+} \mathbf{R}^{+}$and $\mathbf{R}$ ST-L cells and their corresponding isoantisera.

\begin{tabular}{|c|c|c|c|c|}
\hline \multirow{2}{*}{$\begin{array}{l}\text { Test cells: } \\
\text { Isoantisera } \\
\text { raised against }\end{array}$} & $\mathbf{R}^{+} \mathbf{S T}-\mathrm{Ll}$ & $\mathbf{R}^{+}$ST-L4 & R-ST-L9 & R-ST-L22 \\
\hline & \multicolumn{4}{|c|}{ Maximal fluorescence index (Max. titer) } \\
\hline $\mathbf{R}^{+}$ST-Ll & $1.0(32)$ & $1.0(32)$ & $0.5(1)$ & 0.3 \\
\hline $\mathbf{R}^{+} \mathrm{ST}-\mathrm{L} 4$ & $1.0(8)$ & $1.0(16)$ & $0.5(2)$ & 0.3 \\
\hline R'ST-L9 & 0.1 & 0.4 & 0.4 & 0.0 \\
\hline$R^{-}$ST-L22 & 0.0 & 0.0 & 0.1 & 0.3 \\
\hline
\end{tabular}

"Fluorescence index (F.I.): $\frac{a-b}{a}$ where $a$ and $b=$ percentage of fluorescent negative cells treated with normal control serum (a) and with antiserum (b), respectively (11).

Max titer $=\max$. dilution yielding a F.I. $\geqslant 0.5$. 
Table IV.

Indirect immunofluorescence studies reactions of ST-L1 isoantisera with various ST/a mouse lung cells propagated in vitro

\begin{tabular}{|c|c|c|c|c|}
\hline $\begin{array}{l}\text { Cell } \\
\text { line }\end{array}$ & $\begin{array}{l}\text { Round cell } \\
\text { transf. } \\
+/-\end{array}$ & $\begin{array}{l}\text { Tumori- } \\
\text { genic. } \\
+/-\end{array}$ & $\begin{array}{l}\text { PAPA }^{11} \\
+/-\end{array}$ & $\begin{array}{l}\text { Max. F.I. } \\
\text { (Max. titer) }\end{array}$ \\
\hline $\begin{array}{l}\text { ST-L66 } \\
\text { 6. pass. }\end{array}$ & - & - & n.t. & 0.0 \\
\hline $\begin{array}{l}\text { ST-L67 } \\
\text { 7. pass. }\end{array}$ & - & - & n.t. & 0.0 \\
\hline $\begin{array}{l}\text { ST-L67 } \\
\text { 24. pass. }\end{array}$ & - & + & + & 0.0 \\
\hline $\begin{array}{l}\text { ST-L67 } \\
\text { 30. pass. }\end{array}$ & + & + & + & $1.0(32)$ \\
\hline $\begin{array}{l}\text { ST-LI } \\
\text { 389. pass. }\end{array}$ & + & + & + & $1.0(32)$ \\
\hline
\end{tabular}

"see Table II

${ }^{2)}$ see Table III

n.t. $=$ not tested

Table V.

Indirect immunofluorescence studies. Cross-reactions between R'ST-L1, STABAL-2 and Ehrlich cells and their corresponding antisera.

\begin{tabular}{llcl}
\hline $\begin{array}{l}\text { Test cells: } \\
\text { Antisera }\end{array}$ & R'ST-L1 & STABAL-2 & Ehrlich \\
\cline { 2 - 4 } raised against & & Max. F.I. (Max. titer) & " \\
\hline R'ST-L1 & $1.00(32)$ & 0.14 & 0.02 \\
STABAL-2 & 0.29 & 0.02 & - \\
Ehrlich & $0.60(2)$ & - & 0.10 \\
\hline
\end{tabular}

"See Table III

respectively (Table IV). The ST-L67 cell line was tested again in the 24th passage when it had become tumorigenic. At this time the cells were $\mathrm{PAPA}^{+}$and $\mathrm{R}^{-}$. No reactions could be demonstrated with the anti-ST-L1 serum (Table IV). However, a positive reaction comparable to that obtained with the ST-L1 cells was obtained after the 25 th passage during which the ST-L67 cells underwent round cell transformation.

Sera raised against the two non-malignant ST-L66 and ST-L67 cell lines in their 7-14th and 16th-18th passage as well as against primary cultures of ST/a lung tissue and 2 weeks old minced fetal tissue were found to be non-reactive with $\mathrm{R}^{+} \mathrm{ST}-\mathrm{L} 1$ cells. Sera from multipara
ST/a mice ( 5 pregnancies or more) were also inactive (data not presented).

Immunofluorescence studies also included STABAL and Ehrlich ascites tumor cells (Table V). The isoimmunizing properties of these two tumors could not be demonstrated by the indirect membrane immunofluorescence test when the ascites tumor cells served as test cells. These cells also failed to react with anti-ST-L1 sera, but weak to moderate reactions were seen between $\mathrm{R}^{+} \mathrm{ST}$-L1 cells and antisera raised against STABAL and Erhlich.

Table VI shows the results of some experiments in which anti-ST-L1 sera were absorbed with various cell lines or tumors, and subse- 
Table VI.

Indirect immunofluorescence studies. Absorption experiments.

\begin{tabular}{|c|c|c|c|}
\hline $\begin{array}{l}\text { Test cell: } \\
\text { Antiserum }\end{array}$ & \multicolumn{3}{|c|}{$\begin{array}{c}\mathrm{R}^{+} \mathrm{ST}-\mathrm{Ll} \\
\text { Anti-R }{ }^{+} \mathrm{ST}-\mathrm{Ll}\end{array}$} \\
\hline \multirow{3}{*}{$\begin{array}{l}\text { Absorbing } \\
\text { material }\end{array}$} & \multicolumn{3}{|c|}{ Dilution } \\
\hline & $1: 16$ & $1: 32$ & $1: 64$ \\
\hline & \multicolumn{3}{|c|}{ Max. F.I. " } \\
\hline None & 0.96 & 0.93 & 0.72 \\
\hline Normal ST/a lung & 0.74 & 0.93 & 0.72 \\
\hline Ehrlich & 0.84 & 0.53 & 0.34 \\
\hline STABAL-2 & 0.84 & 0.51 & 0.36 \\
\hline $\mathrm{R}^{-} \mathrm{ST}-\mathrm{L} 22$ & 0.74 & 0.42 & 0 \\
\hline $\mathrm{R}^{+} \mathrm{ST}-\mathrm{L} !$ & 0.08 & 0 & 0 \\
\hline
\end{tabular}

"See Table III

quently tested against ST-L1 target cells. Absorption with normal adult ST/a lung tissue and with ST-L1 cells served as negative and positive controls, respectively.

It appears from the table that absorption on Ehrlich, STABAL and ST-L22 cells at a serum dilution of 1:16 only had little or no effect on the immunofluorescence index as compared to normal adult lung. At higher dilutions these cells showed a greater absorbing capacity than lung tissue. We have previously shown (2) that antiST-L1 sera are better absorbed by foetal ST/a tissue than by adult lung. However, the absorbing capacity of cultured $\mathrm{R}^{+} \mathrm{ST}-\mathrm{L} 1$ cells was much stronger than that of any of the other cells and tissues.

\section{IN VITRO STUDIES OF CELL MEDIATED IMMUNITY}

Cell-mediated immunity was studied by a direct microcytotoxicity assay, a direct migration inhibition test, and an indirect test for the production of DNA-synthesis inhibitory lymphokines in vitro.

\section{A. Cytotoxicity assay.}

The cytotoxicity test was carried out as previously described $(8,19)$. It was found that lymph node cells sensitized to $\mathrm{R}^{+} \mathrm{ST}-\mathrm{L} 1$ cells has a significantly stronger cytotoxic effect on these cells than non-sensitized lymphoid cells and lymphoid cells sensitized to primary cultures of ST/a lung or to tumorigenic RST-L66. However, this method was found to be unsuitable for the study of cross-reactions with STABAL and Ehrlich, because these two ascites tumors are not readily grown in vitro (data not presented).

\section{B. Migration inhibition test.}

As shown in Table VII a weak, but significant migration inhibition was obtained with lymph node and thymus cells from ST/a mice immunized with $\mathrm{R}^{+} \mathrm{ST}-\mathrm{L} 1$ and $\mathrm{R}^{-} \mathrm{ST}-\mathrm{L} 22$ cells when the migrating cells were exposed to the sensitizing ST-L cells in the capillary system. However, no cross-reaction could be demonstrated. Table VIII shows a weak cross-reaction between lymphoid cells sensitized to $R^{+}$ST-L1 and STABAL and Ehrlich cells; but this cross-reaction was not confirmed when anti-STABAL or anti-Ehrlich

Table VII.

Migration inhibition test. Cross-reactions between R $^{+}$ST-L1, R'ST-L22 and their corresponding sensitized lymphoid cells studied by the migration inhibition test.

\begin{tabular}{lllll}
\hline \multirow{2}{*}{$\begin{array}{l}\text { Lymphoid } \\
\text { cells }\end{array}$} & $\begin{array}{l}\text { Cells used } \\
\text { for challenge }\end{array}$ & Sens. lymph. & Non-sens, control & Pigration inhibition index \\
\cline { 3 - 5 } & ST-L1 & $0.75 \pm 0.06$ & $0.98 \pm 0.12$ & $0.05-0.025$ \\
\hline Anti-ST-L1 & ST-L22 & $0.58 \pm 0.09$ & $0.71 \pm 0.16$ & $0.10-0.05$ \\
Anti-ST-L1 & ST-L22 & $0.78 \pm 0.05$ & $0.90 \pm 0.02$ & $0.01-0.005$ \\
Anti-ST-L22 & ST-L1 & $0.89 \pm 0.07$ & $0.99 \pm 0.12$ & $0.20-0.10$ \\
Anti-ST-L22 & &
\end{tabular}

${ }^{1)}$ Migration inhibition index (M.I.I.) $=\frac{\text { migration area with antigen }}{\text { mean migration area without antigen }}$ 
Table VIII.

Migration inhibition test. Reactions and cross-reactions between R'ST-L1, Ehrlich and STABAL-2 cells and lymphoid cells sensitized to $\mathbf{R}^{+} \mathbf{S T}-\mathbf{L} \mathbf{L}$.

\begin{tabular}{llll}
\hline \multirow{2}{*}{$\begin{array}{l}\text { Cells used } \\
\text { for challenge }\end{array}$} & \multicolumn{2}{c}{ M.I.I. } & \multicolumn{1}{c}{ P } \\
\cline { 2 - 4 } & $\begin{array}{l}\text { sens.-lymph. } \\
\text { anti-ST-L1 }\end{array}$ & $\begin{array}{l}\text { non-sens. } \\
\text { control }\end{array}$ & $0.05-0.025$ \\
\hline R'ST-L1 & $0.75 \pm 0.06$ & $0.98 \pm 0.12$ & $0.025-0.01$ \\
EHRLICH & $0.78 \pm 0.09$ & $0.94 \pm 0.11$ & $0.05-0.025$ \\
STABAL-2 & $0.76 \pm 0.15$ & $0.93 \pm 0.02$ & \\
\hline
\end{tabular}

"See Table Vll

Table IX.

Migration inhibition test. Reactions and cross-reactions between $\mathbf{R}^{+}$ST-L1 cells and lymphoid cells sensitized to $\mathbf{R}^{+}$ST-L1, Ehrlich and STABAL-2 cells.

\begin{tabular}{|c|c|c|c|}
\hline \multirow{3}{*}{$\begin{array}{l}\text { Antigen } \\
\text { Lymphoid } \\
\text { cells }\end{array}$} & \multicolumn{3}{|c|}{$\mathrm{R}^{+} \mathrm{ST}-\mathrm{L} 1$} \\
\hline & \multicolumn{2}{|c|}{ M.I.I. " } & \multirow[t]{2}{*}{$\mathbf{P}$} \\
\hline & sens. lymph. & non-sens. control & \\
\hline Anti-ST-L1 & $0.75 \pm 0.06$ & $0.98 \pm 0.12$ & $0.05-0.025$ \\
\hline Anti-Ehrlich & $0.79 \pm 0.12$ & $0.88 \pm 0.12$ & $0.20-0.10$ \\
\hline Anti-STABAL-2 & $0.80 \pm 0.17$ & $0.95 \pm 0.10$ & $0.10-0.05$ \\
\hline
\end{tabular}

") See Table VII

Table X.

DNA-synthesis inhibitory lymphokine production in vitro. Reactions and cross-reactions between various ST-L cell lines and their corresponding, sensitized spleen cells.

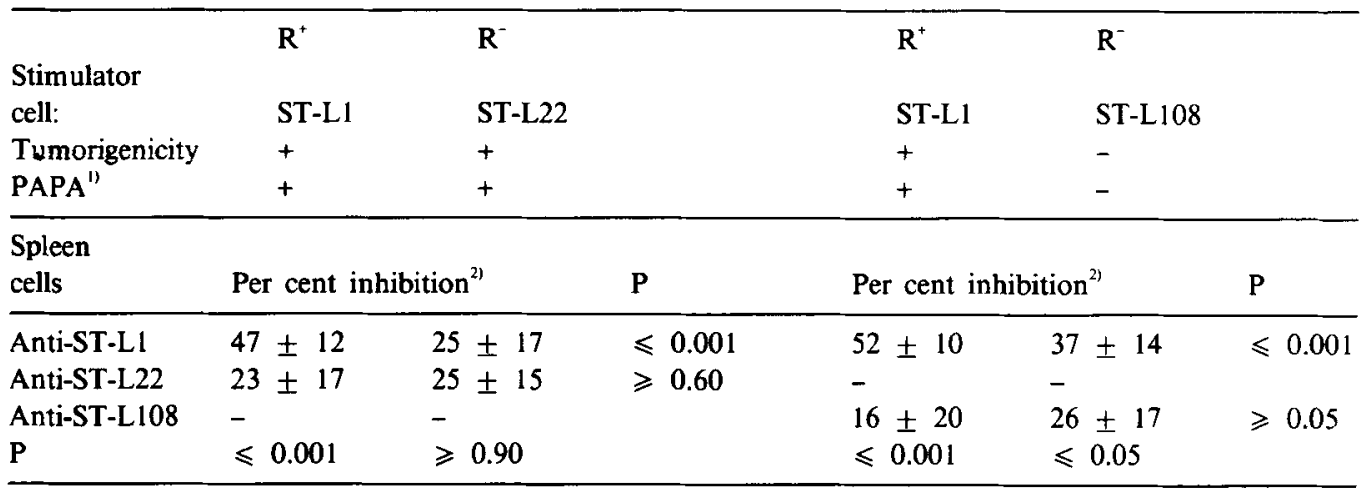

") PAPA = see Table II

2) Per cent inhibition $=\left(1-\frac{a}{b}\right) \times 100$ where a represents the incorporation of ${ }^{3} \mathrm{H}-\mathrm{TdR}(\mathrm{cpm})$ in test cultures treated with supernatants from mixed cultures of stimulator cells and sensitized spleen cells and $b$ the corresponding figures obtained with supernatants from mixed cultures with non-sensitized spleen cells. 
Table XI.

DNA-synthesis inhibitory lymphokine production in vitro. Reactions and cross-reactions between ST-L1 and two ascites tumors and their corresponding, sensitized spleen cells.

\begin{tabular}{|c|c|c|c|c|c|c|}
\hline \multirow{2}{*}{$\frac{\text { Stimulator cell: }}{\text { Spleen cells }}$} & ST-Ll & \multicolumn{2}{|c|}{ STABAL-2 } & ST-LI & \multicolumn{2}{|l|}{ Ehrlich } \\
\hline & \multicolumn{2}{|c|}{ Per cent inhibition" } & \multirow{2}{*}{$\begin{array}{l}P \\
\leqslant 0.001\end{array}$} & \multicolumn{2}{|c|}{ Per cent inhibition ${ }^{13}$} & $\mathrm{P}$ \\
\hline Anti-ST-L1 & $51+9$ & $24+13$ & & $48+13$ & $17+12$ & $\leqslant 0.001$ \\
\hline Anti-STABAL-2 & $19+16$ & $20+14$ & $\geqslant 0.70$ & - & - & \\
\hline Anti-Ehrlich & - & - & & $11+14$ & $16+8$ & $\geqslant 0.20$ \\
\hline $\mathbf{P}$ & $\leqslant 0.001$ & $\geqslant 0.30$ & & $\leqslant 0.001$ & $\geqslant 0.20$ & \\
\hline
\end{tabular}

") See Table $\mathrm{X}$

lymphoid cells were exposed to $\mathrm{R}^{+} \mathrm{S} T-\mathrm{L} 1$ cells (Table IX).

\section{Indirect lymphokine test.}

Cross-reactions between various ST-L cell lines were also tested by their ability to stimulate sensitized spleen cells to produce DNA-synthesis inhibitory lymphokines in vitro. From Table $\mathrm{X}$ it is seen that only weak cross-reactions could be demonstrated between R'ST-LI and R'ST-L22, and between R'ST-L1 and the nontumorigenic ST-L108. Similarly, no or only weak cross-reactions could be demonstrated between $\mathrm{R}^{+} \mathrm{ST}$-Ll and the two ascites tumors, STABAL and Ehrlich (Table XI).

\section{DEMONSTRATION OF INFECTIOUS MuLV}

A. Cross-reactions between $\mathbf{R}^{+} \mathbf{S T}-\mathrm{L}$ cells and ascites tumor cells in vivo and between various ST-L cell lines in vitro.

Extensive cross-reactions between the various cell lines and tumors suggested the presence of common antigens. Most of the cells included in this study expressed MuLV proteins as evidenced by a positive test (PAPA) for $\mathrm{p} 30$. This was confirmed by the demonstration of infectious MuLV by cocultivation of ST-L cell lines with SC- 1 cells and subsequent testing for infectious MuLV by the XC-test. All cell lines produced virus; but detection was first evident in cells cocultivated with STABAL, R-ST-L9 and $\mathrm{R}^{+}$ST-L67 cell lines. SC-1 cells cocultivated with $\mathrm{R}^{+} \mathrm{ST}-\mathrm{L} 1$ and Ehrlich showed plaque formation only after cultivation for 2 weeks or more.

\section{B. Cross-reactions between anti-ST-L sera and SC-1 fibroblasts infected with ST-L virus.}

Assuming that the antigen shared by various ST-L cells may be of viral origin, attempts were made to transfer the specificities detected by isoantisera to virus-free SC-1 mouse fibroblasts. After incubation for 1 hour at $37^{\circ} \mathrm{C}$ the SC-1 cultures received an additional amount of normal medium (MEM) and cultivation was continued. Cultures treated with ST-L1 supernatant were designated STV1/SC-1, and those treated with ST-L22 supernatant STV22/SC-1.

The reactions of these cells with anti-ST-L1 and anti-ST-L22 isoantisera in the indirect membrane immunofluorescence test are shown in Table XII. As it is seen non-treated SC-1 cells did not react with these two antisera. The STV1/ SC-1 cells on the other hand showed a strong reaction and the STV22/SC-1 a somewhat

Table XII.

Indirect immunofluorescence studies. Reactions of $R^{+} S T-L 1$ and $R^{-}$ST-L22 isoantisera with uninfected and infected SC-1 cells.

\begin{tabular}{lll}
\hline \multirow{2}{*}{ Test cells } & \multicolumn{2}{c}{ Antisera } \\
\cline { 2 - 3 } & $\begin{array}{l}\text { Anti-R'ST- } \\
\text { L1 } \\
\text { Max. F.I. }\end{array}$ & $\begin{array}{l}\text { Anti-R } \text { L22 } \\
\text { (Max. titer) }\end{array}$ \\
\hline $\begin{array}{l}\text { SC-1 uninfected } \\
\text { STV1/SC-1-infected } \\
\text { with ST-L1 virus }\end{array}$ & 0.1 & 0.0 \\
$\begin{array}{l}\text { STV22/SC-1-infected } \\
\text { with ST-L22 virus }\end{array}$ & 0.4 & 0.3 \\
\hline
\end{tabular}

"See Table III 
Table XIII.

DNA-synthesis inhibitory lymphokine production in vitro. Reactions and cross-reactions between ST-L1, infected and non-infected SC-1 cells and their corresponding, sensitized spleen cells.

\begin{tabular}{|c|c|c|c|c|c|c|}
\hline \multirow{2}{*}{$\begin{array}{l}\text { Stimulator cells: } \\
\text { PAPA }^{21} \\
\text { Spleen cells }\end{array}$} & $\begin{array}{l}\text { ST-L1 } \\
+\end{array}$ & \multicolumn{2}{|l|}{ SC-1 } & $\begin{array}{l}\text { ST-L1 } \\
+\end{array}$ & $\begin{array}{l}\text { STV1/SC } \\
+\end{array}$ & \\
\hline & Per cent & bition $^{31}$ & $\mathrm{P}$ & Per cent & bition $^{3)}$ & $\mathrm{P}$ \\
\hline Anti-ST-LI & $49+10$ & $22+19$ & $\leqslant 0.001$ & $49+10$ & $45+11$ & $\geqslant 0.30$ \\
\hline Anti-SC-1 & $2+12$ & $21+13$ & $\leqslant 0.005$ & - & - & \\
\hline Anti-STV1/SC-1 & - & - & & $45+14$ & $34+16$ & $\geqslant 0.05$ \\
\hline$P$ & $\leqslant 0.001$ & $\geqslant 0.80$ & & $\geqslant 0.40$ & $\geqslant 0.05$ & \\
\hline
\end{tabular}

"SC-1 cells infected with ST-L1 virus

2) PAPA = see Table II

${ }^{37}$ Per cent inhibition $=$ see Table $\mathrm{X}$

weaker but still clear positive reaction with anti-ST-L1 serum, while only weak or no reactions were obtained with anti-ST-L22 serum.

It therefore appears that at least part of the antigens detected by anti-ST-L1 sera can be transferred with a cellfree supernatant to other cell lines thereby implicating viral proteins as part of the antigenic determinants.

\section{Cross-reactions between $\mathbf{R}^{+}$ST-L1 and} STV1/SC-1 stimulator cells and their corresponding sensitized, lymphokine producing spleen cells.

In agreement with the cross-reaction between anti-ST-L1 sera and ST-L1 virus infected SC-1 cells (STV1/SC-1) these cells stimulated antiST-L1 spleen cells to produce DNA-synthesis inhibitory lymphokine in vitro to the same degree as ST-L1 stimulator cells (Table XIII). Cross-reactions could also be demonstrated between ST-L1 stimulator cells and anti-STV1/ SC-1 spleen cells. In contrast, non-infected SC-1 cells and their corresponding sensitized spleen cells showed little or no activity.

\section{DISCUSSION}

The development of isoimmunizing properties in mammalian cell cultures undergoing apparently spontaneous malignant alteration has been observed by a number of investigators (for review, see 7). Cross-reactions between various cell lines have been demonstrated by transplantation tests and by in vitro tests for cell-me- diated as well as serum-mediated immunity.

However, as demonstrated in the present work the results of various in vivo and in vitro studies do not necessarily correlate with one another. Preimmunization with $\mathrm{R}^{+} \mathrm{ST}$-L 1 cells offered good protection against secondary challenge with STABAL and Ehrlich ascites tumor, but these tumor cells showed only weak or no cross-reactions in vitro with sera raised against $\mathbf{R}^{+} \mathrm{ST}-\mathrm{L}$ 1. Similarly, antisera raised against the two ascites tumors only showed weak to moderate cross-reactions with $\mathrm{R}^{+} \mathrm{ST}-\mathrm{L} 1$ cells in vitro. This is in agreement with other investigators who have observed dissociation between rejection antigens and serologically detectable antigens $(1,6)$.

Some of the common antigens shared by a number of cell lines studied by serological methods in the present investigation were found to be of viral origin. Endogenous leukemia virus (MuLV) is expressed in fetal cells (18), in various types of malignant mouse tumors $(6,15,20)$ and in adult mouse fibroblasts which have undergone apparently spontaneous malignant alteration during propagation in vitro $(4,8,23)$. $\mathrm{MuLV}$ was demonstrated in the present material by various methods.

XC plaque tests demonstrated MuLV production by all the cell lines and tumors examined. However, it is notable that XC plaque formation was not immediately demonstrable in all cases. The ST-L9, ST-L67 and the STABAL gave rise to immediate formation of $\mathrm{XC}$ plaques after cocultivation with $\mathrm{SC}-1$ cells, whereas in all other instances the putative virus- 
infected SC-1 cells had to be passaged one or several times before $\mathrm{XC}$ plaque formation could be demonstrated. It is tentatively concluded from these results that ST-L9, ST-L67 and STABAL have a high production of competent MuLV with a high spread-rate.

The ST-L1 cells have been shown to synthesize a defective virus which converts to a perfect virus after passage in SC-1 cells (21). Synthesis of similar defective viruses could account for the delay in detection in the XC plaque test in most of the cell lines and tumors tested.

In the peroxidase antibody plaque assay a monospecific rabbit antiserum to purified $\mathrm{R}$ MuLV p30 was used (13). With this assay viral protein $\mathrm{p} 30$ was demonstrated in all cell lines tested with the exception of uninfected SC-1 cells and early passages of ST-L108. Early passages of ST-L66 and ST-L67 were not tested, but on later occasions these cell lines were found to be PAPA'.

Anti-ST-L1 serum reacts with SC-1 cells infected with virus produced by ST-LI and STL22 cells indicating that the anti serum contains reactivities directed against viral proteins. This suggests that the humoral cross-reactivities observed in the present study may be partly or wholely of a viral character and directed against proteins of endogenous virus expressed by the cells examined.

Previous immunofluorescence studies with isoantisera raised against $\mathbf{R}^{+} \mathrm{ST}$ - $\mathrm{L}$ cells have revealed a multitude of reactivities. However, in membrane immunofluorescence studies absorption with fetal tissues lowered the titer somewhat (7), and similar results were obtained when immunofluorescence studies were carried out with fixed cells and antisera absorbed with fetal bovine serum (22). In the same investigation it was found that additional absorption with virus-free BALB/3T3 cells removed all tissueculture-cell-specific reactivity leaving an $\mathrm{R}^{+} \mathrm{ST}$ L1 specific antiserum. From this serum all reactivity could be removed by absorption with purified ST-L1 virus. Furthermore, precipitation studies have shown that the specific anti-SL$\mathrm{L} 1$ reactivities are directed against the structural MuLV proteins gp70 and p1S(E) (22).

In the serological studies reported here R'STL22 cells were found to possess an absorbing capacity against anti- $\mathrm{R}^{+} \mathrm{ST}-\mathrm{L}$ serum which did not differ much from that of normal adult ST/a lung tissue. However, in previous studies (22) with high amounts of ST-L22 cells the complete absorption of anti-R $\mathrm{R}^{+} \mathrm{ST}-\mathrm{L} 1$ reactivity showed that all antigenic determinants in the ST-L1 cell line are present in ST-L22.

In the same studies we observed a quantitative difference in the amount of immunoreactive gp70 material between the R ${ }^{+}$ST-L1 and R'STL22 cells by radioimmunoassay, as well as a quantitative difference in the mobility of the glycoproteins by SDS-PAGE (22). These differences in gp70 expression may account for the weak cross-reactions between R'ST-L cells and anti-R ${ }^{+}$ST-L1 sera as well as the observed differences in the immunogenicity of the two types of cells in syngeneic hosts, in which the R'ST-L cells only give rise to very weak antisera.

The expression of MuLV in all cell lines examined by the XC plaque test does not implicate any role of MuLV in the process of $\mathrm{R}^{+}$ transformation. However, it is conceivable that the morphological changes of $\mathrm{R}^{+}$cells, which include the appearance of numerous microvilli on the surface of the cells (9), may favour the presentation of MuLV antigens to the immune apparatus of the recipient. In this connection it is notable that the ST-L67 cell line did not cross-react with anti-ST-Ll serum at the time of malignant alteration, but only one passage later when $\mathbf{R}^{+}$cells appeared in the culture.

Although our present and previous studies indicate that isoantisera raised against ST-L cells may contain antibodies against fetal and "tissueculture-specific" antigens the differences in the humoral immuneresponse to $\mathrm{R}^{-}$and $\mathrm{R}^{+} \mathrm{ST}-\mathrm{L}$ cells are best explained by the differences in the expression of viral antigens between these two types of cells. However, the serological studies fail to explain the differences between $\mathrm{R}^{-}$and $\mathbf{R}^{+}$cells in their protective effect against secondary challenge with STABAL and Ehrlich ascites tumor cells. These tumor cells show no or extremely weak cross-reaction with antisera raised against ST-L cells.

MuLV antigens have also been detected in some chemically induced tumors, and the antibody response to these tumors was found to be directed against the viral antigens (1). Tumors 
not expressing MuLV antigens did not give rise to any antibody production although the tumors expressed individual transplantation antigens. This indicates that transplantation resistance and antibody response are directed against separate antigens.

If this assumption is correct it is conceivable that the specificity defined by cell mediated immune reactions in vitro differs from the specificity defined by serological methods. We have used three methods for the investigation of cell mediated immunity. The micro cytotoxicity assay was found unsuitable for the study of cross-reactions with STABAL and Ehrlich ascites tumor cells, because these cells do not grow very well in vitro. The capillary migration inhibition test only showed weak reactions which in agreement with previous studies carried out with the spleen fragment method (7) failed to reveal any significant cross-reactions between $\mathrm{R}^{+}$and $\mathrm{R}^{-}$cells and their corresponding lymphoid cells. Experiments carried out to elucidate the cross-reactions with STABAL and Ehrlich cells yielded inconsistent results.

Also the indirect DNA-synthesis inhibitory lymphokine test failed to demonstrate immune reactions between the two ascites tumors and anti-R'ST-L1 spleen cells. This method was found to define viral specificities, and the results are in good agreement with the serological studies. However, they did not offer an explanation for the cross-protection of $\mathrm{R}^{+}$cell immunized mice against secondary challenge with STABAL and Ehrlich.

Thus, the question whether in vivo responses and in vitro reactions depend upon two separate antigens remains open. The in vitro reaction has been shown to be due to viral antigens mainly. The in vivo responses may be due to antigens of a different origin. However, studies of the rejection of MSV induced sarcomas have demonstrated an important role of the MuLV helper virus proteins as rejection antigens (3). It cannot be excluded from the present study that similar antigens may be responsible for the cross-reactions observed in our active protection experiments. It is conceivable that these antigens are expressed in different ways under in vivo and in vitro conditions, but it is also possible that their main role in vivo is the T-cell mediated transactivation of macrophages which either attack the tumor cells directly or activate NK or other unspecific killer cells. This might explain the discrepancy between the reactions observed in vivo and in vitro.

\section{REFERENCES}

1. BRown,J.P., J.L. KLITZMAN, I.HELLSTRÖM ET AL.: Antibody response of mice to chemically induced tumors. Proc. Nat. Acad. Sci. USA 75, 955-958 (1978)

2. EAGLE, H.: Amino acid metabolism in mammalian cell cultures. Science 130, 432-437 (1959)

3. Greenberger, J.S. \& S.A. Aaronson: In vivo inoculation of RNA C-type viruses inducing regression of experimental tumors. J. Natl. Cancer Inst. 51, 1935-1938 (1973)

4. Hall, W.T., W.F. ANDRESEn, K.K. Sanford ET AL.: Virus particles and murine leukemia virus complement-fixing antigen in neoplastic and nonneoplastic cell lines. Science 156, 85-88 (1967)

5. HarTley, J.W. \& W.P. Rowe: Clonal cell lines from a feral mouse embryo which lack host-range restrictions for murine leukemia viruses. Virology 65, 128-134 (1975)

6. Hellstróm, K.E., I. Hellstrom \& J.P. Brown: Unique and common tumor-specific transplantation antigens of chemically induced mouse sarcomas. Int. J. Cancer 21, 317-322 (1978)

7. KIELER, J.: Antigenic modification of mammalian cells undergoing "spontaneous" malignant conversion in vitro. Ser. Haematol V 4, 93-122 (1972)

8. KIELER, J., C. RADZIKOWSKI, J. MOORE ET AL:: Tumorigenicity and isoimmunizing properties of $\mathrm{C} 3 \mathrm{H}$ mouse cells undergoing "spontaneous" malignant conversion in vitro. J. Natl. Cancer Inst. 48, 393-405 (1972)

9. Kieler, J., P. BRiand, M.C. van Peteghemet AL.: Comparative studies of two types of "spontaneous" malignant alteration of ST/a mouse lung fibroblasts propagated in vitro. In Vitro 10, 758-771 (1979)

10. KiELER, J., M. KaMinSKI \& K. OSTROWSKJ: Tumor cell stimulation of the production of DNA-inhibitory lymphokines in vitro. Cellular \& Molecular Biology 25, 247-257 (1979)

11. KLEIN, E. \& G. KLEIN: Antigenic properties of lymphomas induced by the Moloney agent. J. Natl. Cancer Inst. 32, 547-568 (1964)

12. Monti-Bragadin, C. \& K. Ulrich: Rescue of the defective murine sarcoma virus from a non-producer hamster tumor cell line with murine and feline leukemia viruses as helpers. Int. J. Cancer 


$$
\text { 9, 383-392 (1972) }
$$

13. MÓLLER, G.: Fluorescent antibody technique for demonstration of isoantigens in mice. Meth. Med. Res. 10, 58-69 (1964)

14. Nexø, B.A.: A plaque assay for murine leukemia virus using enzyme-coupled antibodies. Virology $77,849-852$ (1977)

15. NEXø, B.A. \& H.-H. KROG: C-type virus protein p30 in blood from inbred mice correlates with their later incidence of leukemia. Infect Immunol. 15, 376-381 (1977)

16. OdA, Y., H. HANDA \& J. Kieler: Reevaluation of migration inhibition indices in the immunological study of mice fibroblast transformed spontaneously in vitro. Arch. Jap. Chir. 46, 503-512 (1977)

17. Rowe, W.P., W.E. PUGH \& J.W. HaRtLeY: Plaque assays for murine leukemia viruses. Virology 42 , 1136-1139 (1970)

18. Strand, M., J.T. AuguST \& R. JAENISH: Oncornavirus gene expression during embryonal development of the mouse. Virology 76, 886-890(1977)

19. ULRICH, K. \& J. KIELER: A simple micro tissue culture method for the determination of lym- phocyte cytotoxicity in vitro. Proc. Soc. Exp. Biol. Med. 130, 1297-1301 (1969)

20. Whitmire, C.E., R.A. Salerno, L.S. Rabstein et al.: RNA tumor-virus antigen expression in chemically induced tumors. Virus-genome-specified common antigens detected by complement fixation in mouse tumors induced by 3-methyl-cholanthrene. J. Natl. Cancer Inst. 47, 1255-1265 (1971)

21. Willumsen, B.: In vitro selection of high-infectious, leukemogenic virus from low-infectious, non-leukemogenic type $\mathrm{C}$ from a malignant $\mathrm{ST} / \mathrm{a}$ mouse cell line. J. Virol. 29, 1213-1220 (1979)

22. Willumsen, B., K. Ulrich \& J. Kieler: Serological identification of neoantigens on mouse fibroblasts which have undergone "spontaneous" malignant alteration in vitro. Int. J. Cancer 23, 209-216 (1979)

23. Aaronsen, S.A., J.W. Hartley \& G.J. Todaro: Mouse leukemia virus: "Spontaneous" release by mouse embryo cells after long term in vitro cultivation. Proc. Nat. Acad. Sci. USA 64, 87-93 (1969) 